MINERALOGIA, 39, No. 3-4: 79-85 (2008)

DOI: $10.2478 / v 10002-008-0006-4$

www.Mineralogia.pl

MINERALOGICAL SOCIETY OF POLAND

POLSKIE TOWARZYSTWO MINERALOGICZNE

Original paper

\title{
Orbicular granite near Jelenia Góra in southwestern Poland: the first outcrops?
}

\author{
Pádhraig S. KENNAN ${ }^{1 *}$, Marek W. LORENC²
}

1 School of Geology and Geophysics, University College Dublin, Dublin 4, Ireland; e-mail: padhraig.kennan@ucd.ie

2 Institute of Landscape Architecture, Wroctaw University of Environmental and Life Sciences, pl. Grunwaldzki 24, 50-363 Wrockaw,Poland; e-mail: marek.lorenc@up.wroc.pl

* Corresponding author

Received: April 14, 2008

Accepted: December 11, 2008

Abstract. In 1802, Leopold von Buch described some outcrops of orbicular granite in the Karkonosze granite, Lower Silesia, Poland. In that publication, Abraham Gottlieb Werner wrote a foreword dated 1800. The Silesian discovery predates that of the well-known orbicular diorite (Napoleonite) in outcrop on Corsica and, thus, may be the first ever record of this distinctive rock type in its geological context. The characterizing, closely-packed, simple orbs comprise $\mathrm{K}$-feldspar cores surrounded by rims of radiating K-feldspar and quartz. Rapid growth from a hydrous, pegmatitic melt is indicated. The Karkonosze outcrop, in the timing of its discovery, is a unique part of the geological heritage.

Key-words: orbicular granite, Leopold von Buch, Karkonosze granite, Lower Silesia, Napoleonite

\section{Introduction}

Among granites, diorites and gabbros, orbicular varieties are some of the most striking. Orbicular granites and diorites typically occur as minor bodies near to the mixed margins of larger granite and diorite intrusions; many occurrences are now known worldwide. Orbicular gabbros are reported less frequently. The terms "kugel", "kulisty", "klot" and "ball" are applied to the same rocks in some German, Polish, Scandinavian and English sources respectively.

In typical examples of the texture, the characterizing orbs comprise a core that is granitic, an enclave, or a single mineral grain surrounded by a rim of radiating feldspar with quartz. The rim may be a simple sphere of radiating feldspar or, in more complex cases, involve increments of radial feldspar punctuated by tangential zones of elongate biotite flakes or amphibole. 
The illustrations in the definitive review by Sederholm (1928) reflect the character and diversity of the texture.

This paper concerns an outcrop(s) of orbicular pegmatite in the Karkonosze (Riesengebirge in German) granite intrusion of Carboniferous age in the Polish Sudetes. The purpose is, firstly, to suggest that this particular rock might be deemed the first orbicular granite ever described. The second aim is to reintroduce the work of some Polish and some German geologists to the discussion of orbicular granite - work that for reasons of language, place-name evolution and political history, is rarely referenced. Leveson (1966) is a rare modern exception. In the older literature, the Silesian rock was considered important (e.g., von Chrustschoff 1894; Hatch 1888). The early accounts of Hatch (1888) and Cole (1916) of the orbicular granite at Mullaghderg, Ireland, prompted this examination of the history of the Polish occurrence.

\section{Date of discovery - priority}

The orbicular outcrop(s) in the Karkonosze Granite was briefly described as granite with "kugeln" by von Buch (1802). Von Buch, commissioned in 1796 to make a survey of Silesia as an inspector of mines, worked there from 1796 to 1797. In a short paper written by November 3, 1797, von Buch (1798) described the granite rocks around Bad Warmbrunn (Cieplice today), Schmiedeberg (Kowary) and Hirschberg (Jelenia Góra) but made no reference to kugeln. In the later more comprehensive work (von Buch 1802), these same locations were noted in connection with the small occurrences of orbicular rock. It was in this work that Abraham Werner wrote a foreword dated 1800. Von Buch departed Silesia in September 1797.

However, von Buch had written in 1797 a work entitled "Versuch einer geognostischen Berschreibung von Schlesien" which was accompanied by a map described as very advanced for its time (Noggerath 1853). This map is the Mineralogische Karte von Schlesien published in von Buch (1802). The written work is not listed separately in "von Buchs gesammelte Schriften" (Ewald et al. 1870) presumably because it came to form the first part of the 1802 publication that in which the brief description of the kugel-bearing rock appears.

Thus, the most likely years of formal discovery were 1796 or 1797, though the outcrop might have been found at any time after about 1791 when students of Werner started to work in Silesia. The kugelgranite was originally recorded from as many as four locations, all in the general vicinity of what is now Jelenia Góra (von Buch 1802; Berg 1838).

Orbicular rock from Corsica was already known by this time. In 1785, a large block of orbicular diorite (gabbro), now believed to have been a prehistoric artifact, was discovered there. Granite standing stones (menhirs) are common on the island (see Gauthier and de Lanfranchi 1980). Fragments of the block were sent to Paris. In the first written report, the rock was described as "spheroidal granite" (Besson 1789). Faujas de Saint-Fond was the first to describe the rock as "orbicular" and to illustrate its typical appearance (Faujas de Saint-Fond 1803-1809, Plate XX).

In May 1809, L. Mathieu found and reported the location of the source outcrop at some distance from the place of the original find (Mathieu 1809). Representative samples of Mathieu's material were described in some detail by Pinkerton (1811) and the orbicular granite was illustrated in that same year by Sowerby (1811, Plate 2). Clearly, the rock from Corsica was 
widely known by then. The less-striking Silesian rock was not, though it had been found more than a decade before Mathieu's outcrop discovery.

Mathieu (1813) also described globular porphyries associated with the orbicular rock on Corsica - as did Pinkerton (1811) using samples again supplied by Mathieu. The globules comprise a simple, radiating, spheroidal structure centered on a core (Faujas de Saint-Fond 1803-1809, Plate XX ${ }^{\text {bis }}$ ); these invite comparison with the rock from the Karkonosze Mts.

The Silesian rock, an orbicular pegmatite, shows little of the zonal complexity or visual beauty of the Corsican orbicular diorite; the latter graces many museum collections. The French rock is, of course, that known as corsite and/or napoleonite - widely used as an ornamental decoration, e.g., Napoleon's tomb at Les Invalides, Paris and the Medici Chapelle, Florence. Small decorative objects were being fashioned from it even before the in situ outcrop was found.

\section{Outline history of research on the Lower Silesian orbicular rock}

Of the Karkonosze outcrops of orbicular rock noted by von Buch (1802), only one at Żabieniec Hill at the edge of the village of Czarne (N 50 $53^{\prime} 14,55^{\prime \prime}$; E 15 $40^{\prime} 53,23^{\prime \prime}$ ) in the environs of Jelenia Góra is easily found. Krötenloch is the location name in the older German literature. A second outcrop in the same region at Chojnik (Kynast) castle in the same region, confirmed by Roth (1867), now appears lost. A part of the Czarne outcrop and the detail of a single orb are illustrated in Figure 1.

The original cursory description of von Buch was followed by further brief descriptions by Rose (1842a, b; 1844), Roth (1867) and Klockmann (1882). Von Chrustschoff (1894) in the first detailed account noted a spatial association with pegmatitic schlieren and that orb cores $(80-150 \mathrm{~mm})$, comprising either single crystals of zoned K-feldspar, or fragments of fine-grained granite, were surrounded by fine-grained rims $(50-80 \mathrm{~mm})$. He identified an inner rim of radially arranged quartz and K-feldspar passing outwards into material with a saccharoidal texture. He concluded that the core fragments, whether of feldspar or granite, had been incorporated into the host granite during intrusion and partially resorbed. He recognized that, on cooling, rim crystallization had initially begun from magma immediately surrounding the core, that this magma was enriched in assimilated feldspar material and that the new rim feldspar had grown in crystallographic continuity with the core feldspar. Outwards, as the influence of the core on growth lessened, a more granular texture developed. The enclosing rock, to which the orbs are strongly welded, then crystallized. Clearly, the nucleating role of the core feldspars was appreciated by von Chrustschoff as was their role in contributing material components involved in rim growth. Milch (1898) differed with respect to the origin of the cores - viewing them as cognate host-granite material, not granite or phenocrysts accidentally incorporated.

Johannsen (1932), in summarizing the earlier work, made equivalent use of the terms orb, spheroid and variole. Johannsen's Figure 64 is perhaps the earliest published outcrop photograph. The account of Berg (1938), which also included photographs, addressed the question of further orbicular-granite outcrops in the area and noted Werner's 1800 foreword in von Buch (1802). 
Borkowska (1966, p. 114) briefly described the Karkonosze "granity kuliste" as "orbiculaire" and with "concrétions micropegmatiques à noyaux constitutes de gros cristaux de feldspath potassique rosé interpénétrés d'oligoclase et de biotite".

Karwowski and Kozłowski (1972) identified the "pegmatyt kulisty" as the marginal facies of an aplite vein cutting porphyritic granite. They clearly distinguished the orbicular rock from

a)

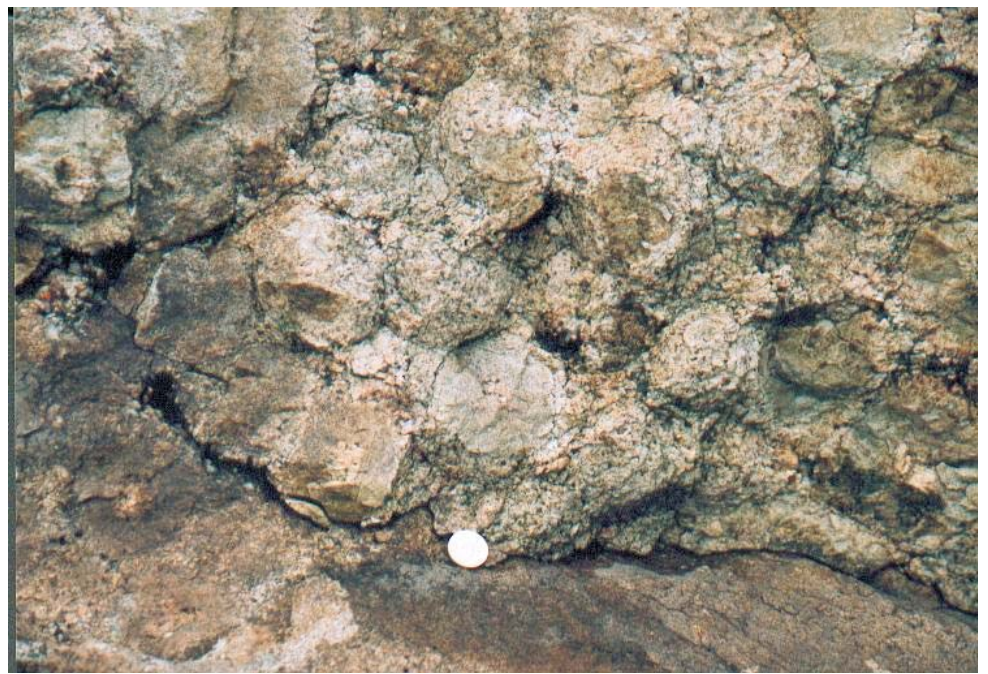

b)

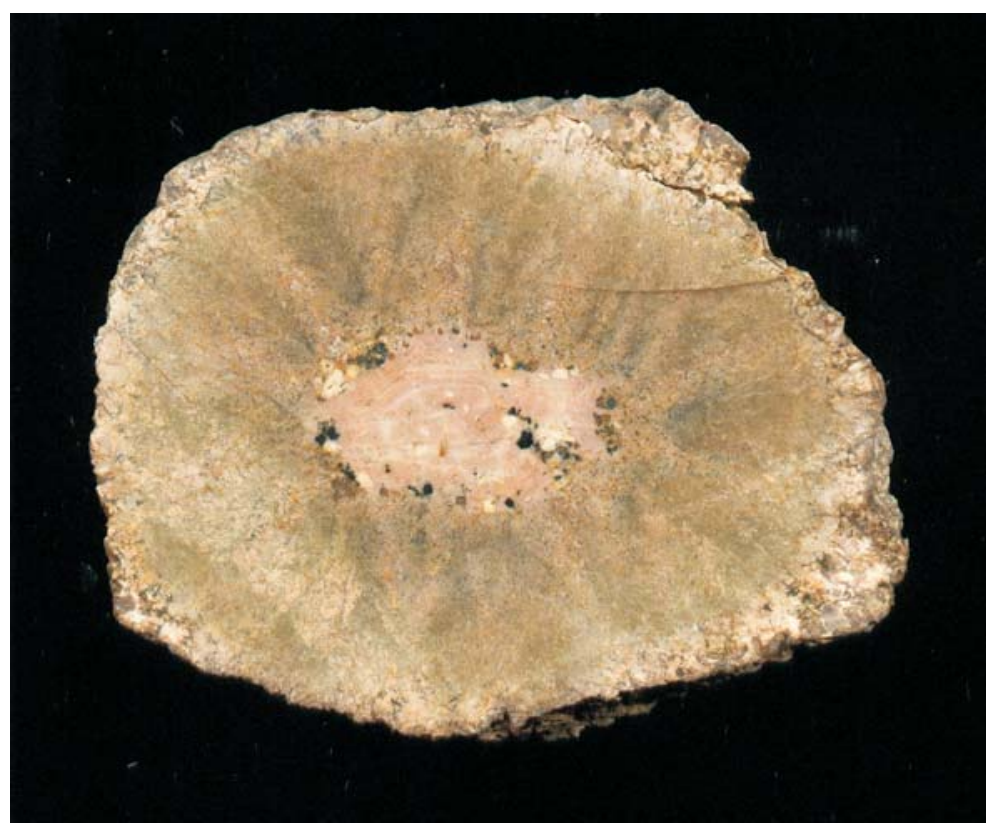

Fig. 1. (a) The Żabieniec Hill orbicular rock on outcrop.

(b) A single orb with a core comprising zoned K-feldspar, biotite and plagioclase surrounded by a simple rim of radiating feldspar and quartz. The diameter of the orb is $80-100 \mathrm{~mm}$ 
an adjacent, orb-free, drusy pegmatite with large microclines, graphic intergrowths, albite, muscovite, quartz and thick biotite plates. In the orbicular rock, large biotites in aggregates characterize only orb cores. In superb illustrations, Karwowski and Kozłowski (op. cit., Fig. 3 and Plate 7) show the twinning of core feldspars reflected in the surrounding rims.

Quartz gas-liquid inclusion data underpinned the conclusion of Karwowski and Kozłowski (1972) that the orbicular rock developed from an aplite melt containing feldspar megacrysts, that the crystallization of the megacrysts - the future orb cores - had occurred at about $640^{\circ} \mathrm{C}$ and that of the feldspar-quartz rims at about $500^{\circ} \mathrm{C}$. They concluded that growth of the rim feldspar and quartz had been promoted by a rapid temperature drop and, probably, gas loss.

Our brief examination of the orbicular rock confirms the older observations. There was no punctuation in the growth event. There is no biotite ordering into concentric zones as in many other occurrences, e.g., the orbicular granite at Mullaghderg in Ireland (Cole 1916). In the Karkonosze rock, the rims of coarse, radiating, feathery feldspar with quartz are, however, richly scattered with small biotite laths. The simplicity of the Polish rock probably reflects the lack of inclusions such as, e.g., biotite schist or amphibolite; there was nothing that could lead to core-surrounding compositional gradients with the potential to spawn Fe-Mg minerals in any quantity. There was little potential, nor time, for rhythmic supersaturation as reflected in the zoned feldspar-biotite rims of the Mullaghderg rock or in the spectacular hornblende-feldspar rims of the Corsican diorite.

\section{Concluding remarks}

The origin of orbicular structure remains a matter of discussion. Moore and Lockwood (1973), in highlighting the comparison with comb layering, provided a significant focus. Vernon (1985) provided another by emphasizing the potential role of superheating.

In the case of the Karkonosze orbicular rock, observations and conclusions by Vernon (1985) and Ort (1992) suggest an applicable model. The hydrous "orbicular" magma was prone to the superheating that effectively eliminated potential nuclei. Thus, there were few nuclei in the "orbicular" magma and many, as is usual, in that of the hosting granite. Pressure changes, related perhaps to intrusion, resulting in the exsolution of water and other volatiles, led to significant undercooling. Rapid crystallization outwards from the few remaining solid cores occurred in essentially one growth phase. There were no granite minerals floating in the immediate vicinity to be trapped within the growing orbs or, if there were, they were pushed away. The drusy cavities in the adjoining orb-free pegmatite reflect the final release, towards the close of crystallization, of the hydrous component that had been critically present throughout. This model differs little from that proposed by Karwowski and Kozłowski (1972).

The concomitant growth of quartz and K-feldspar in poikilitic overgrowths and granophyric intergrowths were important processes in the development of the Karkonosze orbs. The simplicity of this occurrence suggests that it is a close natural analogue of radiating intergrowths of quartz and feldspar experimentally grown from supercooled melt (Baker, Freda 2001 and Fig. 3.57 from Baker in Vernon 2004). The early interchanging of the descriptive terms "orbicular" and "spherulitic" in the early literature is no surprise - and neither would a genetic comparison. 
The outcrop at Czarne is associated with pegmatite in an intrusion in which rapakivi feldspars are common (Borkowska 1966; Słaby and Gotze 2004). London (2005) noted that "whether discussing pegmatites or rapakivi and orbicular granites, the problem is the same; how to explain the origins of complex fabrics, zonation and geochemical and mineralogical peculiarities that distinguish these rocks from ordinary granites". In Karkonosze, they all happen. The orbicular facies of the Karkonosze intrusion might contribute to further understanding of the late, volatile-enriched history of the hosting intrusion - if not treated in isolation and if further outcrops were rediscovered.

The Karkonosze orbicular rock is unique and historically important as the first such recorded an outcrop. It is not likely that an earlier find would have been scientifically documented though it is surely inconceivable that these widespread if unusual, beautiful and mysterious rocks would have drawn the attention of a distant human past only on Corsica.

Acknowledgements. Initial guidance from Professor Bernard Bonin (Universite de Paris-Sud) concerning the discovery history of the orbicular diorite on Corsica was much appreciated. Katarzyna and Paweł Zagożdżon (Technical University, Wroclaw) guided us to the outcrop. Comment by Professor Łukasz Karwowski (University of Silesia, Sosnowiec) was helpful. Tom Culligan (UCD) provided technical support.

\section{References}

BAKER D.R., FREDA C., 2001: Eutectic crystallization in the undercooled Orthoclase-Quartz- $\mathrm{H}_{2} \mathrm{O}$ system: experiments and simulations. European Journal of Mineralogy 13, 453-466.

BERG G., 1938: Kugelgranite im Riesengebirge. Jahrbuch der Preussischen Geologischen Landesanstalt 58, 677-690. BERG G., 1941: Geologische Karte des Deutschen Reiches (1:25000), Lieferung 241, Bad Warmbrunn. 52 pp. Berlin. BESSON M. 1789: Particularites remarquables dans quelques granites et roches primitives. Journal de Physique de I'Abbé Rozier (or Rozier's Journal) 35,121-131.

BORKOWSKA M., 1966: Petrografia granitu Karkonoszy. Geologia Sudetica 2, 7-119 (in Polish with extended French summary)

COLE G.A.J., 1916: On the mode of occurrence and origin of the orbicular granite at Mullaghderg, Co. Donegal. Proceedings of the Royal Dublin Society 15,141-158.

EWALD J., ROTH J., ECK H., (Eds), 1870: Leopold von Buchs gesammelte Schriften. Reimer Berlin. (edoc Server, Humboldt Universität, Berlin).

FAUJAS de SAINT-FOND B., 1803-1809: Essais de géologie, ou mémoires pour servire a l'histoire naturelle du globe, Paris, vol. 2 (Minéraux). Paris, 600 pp.

GAUTHIER A., de LANFRANCHI F., 1980: La diorite orbiculaire: histoire d'une découverte. Bulletin Société Prehistorique Francais 77, 280-282.

HATCH F.H., 1888: On the spheroid-bearing granite of Mullaghderg. Quarterly Journal of the Geological Society of London 44, 548-560.

JOHANNSEN A., 1932: A descriptive petrography of the igneous rocks, Volume II: The quartz-bearing rocks. University of Chicago Press, 248-259.

KARWOWSKI L., KOZŁOWSKI A., 1972: Pegmatyt kulisty z Czarnego koło Jeleniej Góry. Acta Geologia Polonica 22, 93-108 (in Polish with English summary).

KLOCKMANN F., 1882: Beitrag zur Kenntniss der granitischen Gesteine des Riesengebirges. Zeitschrift der Deutschen Gesellschaft für Geowissenschaften 34, 373-426.

LEVENSEN D.J., 1966: Orbicular rocks: A review. Bulletin of the Geological Society of America 77, 409-426.

LONDON D., 2005: Granitic pegmatites: an assessment of current concepts and directions for the future. Lithos 80, 281-303. 
MATHIEU L., 1809: Notice sur la découvert de plusiers blocs de granit orbiculaire nouvellement trouvés en Corse, dans l'arrondissement de Sartene. Annales du Muséum National d'Histoire Naturelle de Paris 14, 82-84.

MATHIEU L., 1813: Notice sur les guisements de granite et du porphyre globuleux trouvés en Corse. Annales des Mines de France 34, 105-116.

MILCH L., 1898: Beiträge zur Kenntnis der granitischen Gesteine des Riesengebirges. I. Neues Jarbuch für Mineralogie (Beil.-Bd) 12, 1898, 115-237.

MOORE J.G., LOCKWOOD J.P., 1973: Origin of comb layering and orbicular structure, Sierra Nevada Batholith, California. Bulletin of the Geological Society of America 84, 1-20.

NOGGERATH M., 1853: Biography of the celebrated geologist, Baron Leopold von Buch. The Edinburgh New Philosophical Journal 55, 1-13.

ORT M., H., 1992: Orbicular volcanic rocks of Cerro Panizos: Their origin and implication for orb formation. Bulletin of the Geological Society of America 104, 1048-1058.

PINKERTON J., 1811: Petrology. A Treatise on Rocks: Volume 2. White, Cochrane and Co., London, 656 pp.

ROSE G., 1842a: Über den Granit des Riesengebirges. In: Bericht über die zur Bekanntmachung geeigneten Verhandlungen der Königl. Preussischen Academie der Wissschaften zu Berlin, 247-254.

ROSE G., 1842b: Granit von Schwarzbach und Kynast bei Warmbrunn in Schlesien. Poggendorf's Annalen, Band LVI, $617-625$.

ROSE G., 1844: (Untitled note on Granite des Riesengebirges). Neues Jahrbuch für Mineralogie, Geognosie, Geologie und Petrefakten-Kunde. 445-447.

ROTH J., 1867: Erläuterungen zu der geognostischen Karte von Niederschlesien Gebirge und den umliiegunden Gegenden. Commissiomns-Verlag der Neumann'schen Kartenhandlung, Berlin.

SEDERHOLM J. J., 1928: On orbicular granites, spotted and nodular granites, etc., and on the rapakivi texture. Commission Géologique de Findlande Bulletin 22, 93-107.

SŁABY E., GÖTZE J., 2004: Feldspar crystallization under magma-mixing conditions shown by cathodoluminescence and geochemical modelling - a case study from the Karkonosze pluton (SW Poland). Mineralogical Magazine 68, $541-557$.

SOWERBY J., 1811-1820: Exotic Mineralogy: Or Coloured Figures of Foreign Minerals as a Supplement to British Mineralogy. London.

VERNON R.H., 1985: Possible role of superheated magma in the formation of orbicular granitoids. Geology 13, $843-845$

VERNON R. H., 2004: A practical guide to Rock Microstructure. Cambridge University Press, 594 pp.

VON BUCH L., 1797: Ueber das Riesengebirge. Schlesische Provinzialblätter 27, 528-536.

VON BUCH L., 1802: Geognostische Beobachtungen auf Reisen durch Deutschland und Italien, Band 1, Entwurf einer geognostischen Berscreibung von Schlesien, 13-28.

VON CHRUSTSCHOFF K., 1894: Über holokrystalline makrovariolithische gesteine. Mémoires de l'Académie Impériale des Sciences de St.-Pétersbourg, VII Serie, Tome 42, No. 3, 59-89. 